\title{
Determinants of Households' Adaptation Practices against Climate Change Impact on Off- farm Activities in Western Hill of Nepal
}

\author{
Ananta Raj Dhungana ${ }^{1^{*}}$, Vikash Kumar KC ${ }^{2}$, Purna Bahadur Khand ${ }^{3}$ and Surya Mani Dhungana ${ }^{4}$ \\ ${ }^{1}$ School of Development and Social Engineering, Pokhara University, Pokhara, Nepal \\ ${ }^{2}$ Department of Statistics, Tribhuvan University, PN Campus, Pokhara, Nepal \\ ${ }^{3}$ School of Business, Pokhara University, Pokhara, Nepal \\ ${ }^{4}$ Agriculture and Forestry University, Rampur, Nepal
}

Email: anantastat@gmail.com, ${ }^{2}$ vkkc2001@gmail.com, ${ }^{3}$ purnabahadurkhand@gmail.com,

${ }^{4}$ smdhungana@afu.edu.np

Corresponding Author: Ananta Raj Dhungana

\begin{abstract}
Climate change is one of the serious concerns which have a substantial impact in all areas of human civilization. Among these areas, agriculture is the worst hit sector. This study aims to analyze the determinants of households' adaptation practices against climate change impact on off-farm activities in western hill of Nepal. It utilizes the data collected from six village development committees from three districts (Lamjung, Tanahu and Kaski) of western hill of Nepal. Out of 245793 Households 556 households were chosen for the survey. A systematic random sampling technique was used to select the respondents. Data was collected using pre-tested structured questionnaire through face to face interview with household head or a household member having age 45 years and above with residing in that locality since last 15 years. Binary logistic regression analysis has been carried out. Household size is only the matter for determining the households' adaptation practices for shifting to non-agricultural activities which is also the matter for temporary migration to another places. Education is the determining factor for changing the food consumption habit and temporary migration. Agriculture skill is the common determining factor for change in food consumption habit and shifting to non-agricultural activities. Sex and marital status are the major determining factors only for shifting to non-agricultural employment. Age is the significant predictor of temporary migration. Caste is also the major determining factor for changing the food consumption habit and temporary migration respectively.
\end{abstract}

Keywords: Food consumption, Non-agriculture activities, Non-agriculture employment, Off-farm, Temporary migration.

\section{Introduction}

Climate change is a universal phenomenon affecting various sectors in the world and is reflected to be one of the most serious threats to human civilization. Globally, an exceptional increase in greenhouse emissions has led to increased climate change impacts. Agriculture is one the most influenced sectors due to the climate change. Farmers have been facing unfavorable production situation due to the impact of climate change all over the world and this is more intense where the agriculture related infrastructure are weak and not well developed (Lien, Kumbhakar \& Hardaker, [8]). Such unfavorable situations increase the cost of production creating an inability to sell the production in competitive markets. So the farmers seek to adapt alternative options that have low risk of loss. Off farm activities may be the safe exit for avoiding the risks of climate change impact among farmers. 
Nepal is one of the most vulnerable countries in terms of climate change, due to greater warming in recent years than that of the global trend. While there was $0.6^{\circ} \mathrm{C}$ global mean surface temperature rise, from 1975 to 2005 , Nepal experienced a considerably higher temperature rise of $1.5^{\circ} \mathrm{C}\left(0.06^{\circ} \mathrm{C}\right.$ per year) during a similar duration of time, from 1982 to 2006 (Shrestha, Gautam and Bawa, [12]). Similarly, the rainfall patterns are also becoming more erratic and decreasing (Wang, Yoon, Gillies and Cho, 2013). The mean rainfall has been decreasing by $3.7 \mathrm{~mm}(-3.2 \%)$ per month, per decade (MoE, [10]). These conditions have created a drought especially for the rain-fed hill farming system, where people depend on summer and winter rainfall for their major agricultural activities (Ghimire, Shivakoti \& Perret, [5]). Moreover, the mean annual temperature is predicted to be increased between $1.3{ }^{\circ} \mathrm{C}$ to $3.8{ }^{\circ} \mathrm{C}$ by the $2060 \mathrm{~s}$, and $1.8{ }^{\circ} \mathrm{C}$ to $5.8{ }^{\circ} \mathrm{C}$ by the 2090 s while annual precipitation reduction could be within the range of $10 \%$ to $20 \%$, across the country (MoE, [10]).

Adaptation is an adjustment in natural or human systems in response to actual or expected climatic conditions or risks and can be regarded as a policy option to contain the negative effects of climate change (Kurukulasuriya and Mendelsohn, [7]). Adaptation is the most efficient way out for them to face the extreme weather conditions associated with climate variations and to minimize the negative impacts of climate change (IPCC, [6]). The adaptation strategies of farmers employed to mitigate the effect of climate change include varying land size, varying the planting and harvesting dates; soil conservation techniques and mulching. Other adaptation strategies include, livestock rearing; mixed cropping, monocropping and no adaptation. Other socioeconomic adaptation measures, which help to combat the underlying causes of vulnerability and improve the adaptive capacity of farmers, must be considered. The measures taken, aimed at reducing the vulnerability of agricultural areas, depend on the resources and features of each area, as indicated so far. There will be a need to shift from certain crops to others that are more resistant and better adapted to the 'new' climate, or to abandon agricultural production in the more exposed areas in favor of other economic activities. In the latter case, the management of diversification off-farm needs to be managed as part of a broader economic transition. Off-farm activities involve participation in remunerative work outside the participant's own farm and have been recognized to play an increasingly essential role in sustainable development and poverty reduction particularly in rural areas (Food and Agriculture Organization, [3]). It may serve as a safety net for the poor whereas for the rich it may be a means of accumulation. It can create opportunities to explore different adaptations strategies like change in food consumption habit, off farm activities, off farm job and temporary migration that are suitable in such changing circumstances. However, despite the growing body of knowledge attached to climate change adaptation strategies (Fasona, Tadross, Abiodun and Omojola, [4]), very few of such studies have analyzed the factors influencing adaptation in Nepalese context but there is no research on participation in off-farm activities as an adaptation strategy against climate change by farmer in the Nepal. As such, a clear understanding of the determining factors that influence farmers' adaptation decisions is essential to the designing of appropriate policies to promote effective adaptation in the agricultural sector (Mabe, Gifty and Samuel, [9]). That might be forwarding to wider the eyes of policy maker as well as farmer who are really victimized. Several studies conducted around the globe claim that education, caste, household size, sex, age and agriculture experience of the farmers have been found determining factors related to off-farm activities (Dhungana and Khand, [1]; Dhungana, KC, Khand and Dhungana, [2]). Therefore, this study aims to identify the determinants of household adaptation strategies of climate change impact on off-farm activities in western hill of Nepal. 


\section{Materials and Methods}

Three districts (Lamjung, Kaski and Tanahu) from hill region which are more vulnerable in terms of climatic hazards and have a wider variation in temperature and rainfall have been chosen for this study. A national adaptation program of action (NAPA) to climate change has also identified Lamjung as very high (0.787 - 1.000), and Kaski \& Tanahu as moderate (0.356 - 0.600) vulnerability ranking (MoE, [10]).

For primary data collection, a multistage sampling technique was used. Initially six villages lying along a traverse across the three topographical regions in north-south direction of the western hill region were chosen from the sample districts. At the next stage, 556 households (164 out of $42048 \mathrm{HHs}$ from Lamjung, and 168 out of 125459 HHs from Kaski, 224 out of 78286HHs from Tanahu districts) using proportional allocation (based on the number of households in the selected sites) were selected using systematic random sampling (CBS, 2014). The calculation of sample size was based on the assumption of about $50.0 \%$ of people know about climate change and its impact on agriculture (CBS, 2016) with 95.0 $\%$ confidence interval and $4.5 \%$ of margin of error which gave 475 samples. Additional 15.0\% (71 households) samples were added for addressing non-response. This gave the minimum sample of 546 for the study. For systematic random sampling, number of households for each ward was obtained from the latest population and housing census 2011. Then first household was chosen randomly starting from north-east corner of each ward. Remaining households were selected in clockwise direction at the interval of 5 households in Lamjung, 6 households in Tanahu and 4 households in Kaski districts. Finally, household head or a household member of age 45 years and above, residing in that area for the last 15 years at the time of the survey was chosen as a respondent. Only one respondent was selected from a selected household.

A rigorous literature review was done for developing research tools and was also consulted with experts for maintaining the validity. After pre-testing of 55 questionnaires; 25 in ward 33 of Pokhara metropolis of Kaski and 30 in Rupa rural municipality of Kaski districts, few modifications were made before finalizing the instrument. Information on change on food consumption habit; shifting to non-agricultural activities; shifting to non-agricultural employment; and temporary out-migration have been chosen as offfarm activities. Age, sex, marital status, educational status, caste/ethnicity, religion, household size, agriculture skill and years of experience in agricultural sector have been considered as the set of independent variables because the existing literature has also used these variables as the set of independent variables (Oppong-Kyeremen and Bannor, [11]).

For multivariate analyses, binary logistic regression models have been carried out to find the determinants of adaptation practices on off-farm activities. In binary logistic regression, the response variable contains two categories like true and false etc.

Mathematical form of binary logistic equation is given as

$$
P=\frac{1}{1+\operatorname{Exp}(-Z)} \text {,where, } P=\text { estimated probability, } \mathrm{Z}=\text { predictor }
$$

Let $Y$ be the binary outcome variable indicating failure/success with $0 / 1$ and $P$ be the probability of $Y$ to be 1, i.e. $P=\operatorname{prob}(Y=1)$.Let $X_{1}, \ldots, X_{\mathrm{k}}$ be a set of predictor variables. Then the logistic regression of $Y$ on $X_{1}, \ldots, X_{k}$ estimates parameter values for $b_{0}, b_{1}, \ldots, b_{k}$. For the multivariate case, $\mathrm{Z}$ can be expressed in terms of linear combination of other predictor variables as $Z=b_{0}+b_{1} X_{1}+b_{2} X_{2}+\ldots \ldots+b_{n} X_{n}$ then the logistics function reduces to the form 


$$
P=\frac{1}{1+\operatorname{Exp}\left[-\left(b_{0}+b_{1} X_{1}+b_{2} X_{2}+\ldots \ldots . .+b_{n} X_{n}\right)\right]}
$$

The ratio of probability of success and not success is also known as Odd ratio i.e.

$$
\text { Odds }=\frac{P}{1-P}
$$

Hence the binary logistic function reduces to the form

$$
\text { LogitP }=b_{0}+b_{1} X_{1}+b_{2} X_{2}+\ldots \ldots \ldots+b_{n} X_{n}
$$

Logistic regression can also be expressed as in probability form

$$
P(x)=\frac{\operatorname{Exp}\left(b_{0}+b_{1} X_{1}+b_{2} X_{2}+\ldots \ldots \ldots+b_{n} X_{n}\right.}{1+\operatorname{Exp}\left(b_{0}+b_{1} X_{1}+b_{2} X_{2}+\ldots \ldots \ldots+b_{n} X_{n}\right.}
$$

\section{Results}

Sex of the respondent, caste/ethnicity, marital status, religion, family type, family size, age, educational status, farming experience, agriculture skill and major occupation of the household are the main socioeconomic and demographic variables considered for the analysis.

Nearly $2 / 3$ of the respondents $(65.1 \%)$ are male. The minimum age of the respondents is 45 years and the maximum age is 92 years with the average age as 56.55 years. More than nine-tenths $(93.9 \%)$ of the respondents are married. The average family size is 5.93 which is greater than the national average (4.88). More than half $(56.5 \%)$ of the respondents are Janajati followed by Brahmin (19.1\%), Dalit (13.3\%), Chhetri (8.3\%), Muslim (1.4\%), and others (1.4\%). More than 2/3 (71.8\%) follow the Hindu religion followed by Buddhists (22.5\%), Muslim (1.4\%), Christian (0.7\%), and others (3.6\%) respectively. Almost nine-tenths $(88.3 \%)$ of the respondents do not have any agriculture skills. The minimum farming experience of the respondents is 15 years and the maximum is 70 years with a mean 31.25 years. More than $1 / 3(36.0 \%)$ of the respondents have basic education followed by informal education (33.1\%), illiterate $(15.1 \%)$, secondary education $(13.1 \%)$, and higher education $(2.7 \%)$ respectively. More than nine-tenths $(92.8 \%)$ of the respondents have agriculture as a major occupation followed by government services $(2.3 \%)$, private sectors $(1.4 \%)$, business $(1.3 \%)$, and others $(2.2 \%)$ respectively.

Table 1: Background Characteristics of Respondents

\begin{tabular}{lll}
\hline Background Characteristics & Number & $\%$ \\
\hline
\end{tabular}

Age (years)

Minimum $=45$, Maximum $=92$, Average $=56.55$ with S.D. $=9.29$

Sex of the respondents

Male

362

Female

194

18

522

16

Divorced
65.1

34.9

3.2

93.9

2.9

Family size

Minimum $=1$, Maximum $=19$, Average $=5.93$ with S.D. $=2.80$

\section{Caste/ethnicity*}




\begin{tabular}{|c|c|c|}
\hline Brahmin & 106 & 19.1 \\
\hline Chhetri & 46 & 8.3 \\
\hline Janajati & 314 & 56.5 \\
\hline Dalit & 74 & 13.3 \\
\hline Muslim & 8 & 1.4 \\
\hline Others & 8 & 1.4 \\
\hline \multicolumn{3}{|l|}{ Family type } \\
\hline Joint & 320 & 57.6 \\
\hline Nuclear & 236 & 42.4 \\
\hline \multicolumn{3}{|l|}{ Religion } \\
\hline Hindu & 399 & 71.8 \\
\hline Buddhist & 125 & 22.5 \\
\hline Christian & 4 & 0.7 \\
\hline Muslim & 8 & 1.4 \\
\hline Others & 20 & 3.6 \\
\hline \multicolumn{3}{|l|}{ Agriculture skill } \\
\hline Yes & 65 & 11.7 \\
\hline No & 491 & 88.3 \\
\hline \multicolumn{3}{|c|}{ Farming experiences(years) } \\
\hline \multicolumn{3}{|c|}{ Min $=15$, Max. $=70$, Mean $=31.25$, with S.D. $=12.06$} \\
\hline \multicolumn{3}{|c|}{ Educational status of respondent } \\
\hline Illiterate & 84 & 15.1 \\
\hline Informal Education & 184 & 33.1 \\
\hline Basic Education & 200 & 36 \\
\hline Secondary Education & 73 & 13.1 \\
\hline Higher Education & 15 & 2.7 \\
\hline \multicolumn{3}{|c|}{ Major occupation of the household } \\
\hline Agriculture & 516 & 92.8 \\
\hline Government Service & 13 & 2.3 \\
\hline Private services & 8 & 1.4 \\
\hline Business & 7 & 1.3 \\
\hline Others & 12 & 2.2 \\
\hline
\end{tabular}

Source: Field Survey, 2019

Note: *Janajati includes Gurung, Magar, Rai, and Tamang while Dalit represents Kami, Sarki and Damai

\section{Adaptation practices toward off-farm activities}

Among the various off-farm strategies adapted by the households, only four strategies: change in food consumption habits, involvement in non-agricultural activities, involvement in non-agricultural employment and migration of any household members to another place within 15 years have been considered as non-farm activities for analytical purpose. More than half of the respondents changed their food consumption habit for the adaptation of climate change. Just over one tenth of the households have shifted to non-agricultural activities and $5 \%$ of households have shifted to non-agricultural employment. Similarly, only just over $7 \%$ have migrated temporarily from that place for the adaptation of climate change (table 2). 
Table 2: Adaptation Practices towards Off-farm Activities

\begin{tabular}{lcc}
\hline Characteristics & Number & $\mathbf{\%}$ \\
\hline Change in food consumption habit & 243 & \\
Yes & 313 & 43.7 \\
No & 56 & 56.3 \\
Involvement in non-agricultural activities & \\
Yes & 500 & 10.1 \\
No & 28 & 89.9 \\
Involvement in non-agricultural employment & \\
Yes & 528 & 5.0 \\
No & 95.0 \\
Migration of any member of HH to another place within $\mathbf{1 5}$ years \\
Yes & 42 & 7.6 \\
No & 514 & 92.4 \\
Total & $\mathbf{5 5 6}$ & $\mathbf{1 0 0}$ \\
\hline
\end{tabular}

Source: Field Survey, 2019

Determinants of households' adaptation practices against climate change impact on off-farm activities

To find the determinants of households' adaptation practices against climate change impact on off-farm activities, change on food consumption habit; shifting to non-agricultural activities; shift to nonagricultural employment; and temporary out-migration have been considered as dependent variables while age, sex, marital status, religion, household size, educational status, caste/ethnicity, agricultural skill and years of experience in agricultural sector are considered as independent variables.

\section{Change of food consumption habit}

Table 3 shows the adjusted odds ratio (from logistic regression analysis) with their $p$-values and confidence intervals $(\mathrm{CI})$. From the model, analyses reveal that literate people are more likely to change the food consumption habits than illiterate people. However, with reference to upper caste, Janajati people are less likely to change of the food consumption habits. Similarly with reference to people with agriculture skill, people without agriculture skill are 2.034 times more likely to adapt such practice.

Table 3: Odds ratio from Logistic Regression Model of Change of the Food Consumption Habits $(n=556)$

\begin{tabular}{lccc}
\hline Characteristics & Odds Ratio & \multicolumn{2}{c}{ 95\% CI } \\
& & Lower & Upper \\
\hline Age & 1.004 & 0.985 & 1.037 \\
Sex & & & \\
Male (R) & 1 & & \\
Female & 1.281 & 0.891 & 1.842 \\
Marital status & & & \\
Married (R) & 1 & & \\
Single & 0.622 & 0.299 & 1.335 \\
Religion & & & \\
Hindu (R) & 1 & & \\
Non-Hindu & 0.928 & 0.606 & 1.419
\end{tabular}

Education 
Illiterate $(\mathrm{R})$

Literate

1

Caste/Ethnicity

Upper Caste (R)

Janajati

$1.603^{*}$

1.034

2.486

Others

$0.469 * * *$

0.294

0.749

Household size

$0.573 *$

0.329

0.999

Agriculture skill

0.991

0.929

1.058

Yes (R)

1

No

$2.034 * * *$

1.211

3.414

Years of experience

on agriculture

$0.986 \quad 0.967 \quad 1.005$

Note: Final -2loglikelihood $=729.281 ;$ Hosmer and Lemeshow - Chi-square value $=5.655 \quad(p=0.686)$

; NagelkerkeR ${ }^{2}=0.096$; Cox-Snell $\mathrm{R}^{2}=0.072$

$* \mathrm{P}<0.05, * * \mathrm{P}<0.01$ and $* * * \mathrm{P}<0.001$

\section{Shifting to non-agricultural activities}

Shifting to non-agricultural activities has two responses yes and no. No is taken as reference category for finding the determinants of adaptation practices. Table 4 shows the odds ratio from logistic regression analysis of shifting to non-agriculture activities with $p$-values and confidence intervals. Analyses reveal that, as household size increases, there is more likely to shift to non-agricultural activities.

Table 4: Odds Ratio from Logistic Regression Model of Shifting to Non-agricultural Activities ( $n=556)$

\begin{tabular}{|c|c|c|c|}
\hline \multirow[t]{2}{*}{ Characteristics } & \multirow[t]{2}{*}{ Odds Ratio } & \multicolumn{2}{|c|}{$95 \% \mathrm{CI}$} \\
\hline & & Lower & Upper \\
\hline Age & 1.008 & 0.980 & 1.037 \\
\hline \multicolumn{4}{|l|}{ Sex } \\
\hline Male (R) & 1 & & \\
\hline Female & 1.247 & 0.690 & 2.255 \\
\hline \multicolumn{4}{|l|}{ Marital status } \\
\hline Married(R) & 1 & & \\
\hline Single & 0.972 & 0.274 & 3.451 \\
\hline \multicolumn{4}{|l|}{ Religion } \\
\hline $\operatorname{Hindu}(\mathrm{R})$ & 1 & & \\
\hline Non-Hindu & 1.040 & 0.500 & 2.164 \\
\hline \multicolumn{4}{|l|}{ Education } \\
\hline Illiterate $(\mathrm{R})$ & 1 & & \\
\hline Literate & 0.636 & 0.271 & 1.494 \\
\hline \multicolumn{4}{|l|}{ Caste/Ethnicity } \\
\hline Upper Caste(R) & 1 & & \\
\hline Janajati & 1.439 & 0.713 & 2.907 \\
\hline Others & 2.527 & 0.904 & 7.067 \\
\hline Household size & $1.143^{*}$ & 1.003 & 1.303 \\
\hline \multicolumn{4}{|l|}{ Agriculture skill } \\
\hline Yes(R) & 1 & & \\
\hline No & 1.831 & .893 & 3.756 \\
\hline Years of experience & 1.015 & .983 & 1.048 \\
\hline
\end{tabular}




\section{on agriculture}

Constant $0.019 * *$

Note: Final -2loglikelihood $=353.552$; Hosmer and Lemeshow - Chi-square value $=12.717(\mathrm{p}=0.122)$; Nagelkerke $\mathrm{R}^{2}=0.704$; Cox-Snell $\mathrm{R}^{2}=0.528$

$* \mathrm{P}<0.05, * * \mathrm{P}<0.01$ and $* * * \mathrm{P}<0.001$

\section{Shifting to non-agricultural employment}

The dependent variable shifting to non-agricultural employment has two responses i.e. yes and no assuming no as reference category. Table 5 shows the odds ratio from logistic regression analysis. As age increases, there is more likely to shift to non-agricultural employment. Female are 4.44 times more likely to shift to non-agricultural employment than male. Similarly with reference to people with agriculture skill, people without agriculture skill are 2.8 times more likely to shift into non-agricultural employment. However, with reference to married people, single people are less likely to have such adaptation practice.

Table 5: Odds ratio from Logistic Regression Model of shifting to Non-agricultural Employment $(n=556)$

\begin{tabular}{|c|c|c|c|}
\hline \multirow[t]{2}{*}{ Characteristics } & \multirow[t]{2}{*}{ Odds Ratio } & \multicolumn{2}{|c|}{$95 \% \mathrm{CI}$} \\
\hline & & Lower & \\
\hline Age & 1.037 & 0.998 & 1.078 \\
\hline \multicolumn{4}{|l|}{ Sex } \\
\hline Male (R) & 1 & & \\
\hline Female & $4.443 * * *$ & 1.590 & 12.416 \\
\hline \multicolumn{4}{|l|}{ Marital status } \\
\hline Married & 1 & & \\
\hline Single & $0.199 *$ & 0.056 & 0.706 \\
\hline \multicolumn{4}{|l|}{ Religion } \\
\hline Hindu & 1 & & \\
\hline Non-Hindu & 0.600 & 0.213 & 1.692 \\
\hline \multicolumn{4}{|l|}{ Education } \\
\hline Illiterate(R) & 1 & & \\
\hline Literate & 1.566 & 0.614 & 3.997 \\
\hline \multicolumn{4}{|l|}{ Caste/Ethnicity } \\
\hline Upper Caste(R) & 1 & & \\
\hline Janajati & 2.262 & 0.726 & 7.045 \\
\hline Others & 0.538 & 0.188 & 1.540 \\
\hline $\begin{array}{l}\text { Household size } \\
\text { agriculture skill }\end{array}$ & 1.024 & 0.885 & 1.184 \\
\hline Yes(R) & 1 & & \\
\hline No & $2.804 *$ & 1.053 & 7.466 \\
\hline $\begin{array}{l}\text { Years of experience } \\
\text { on agriculture }\end{array}$ & 0.973 & 0.932 & 1.015 \\
\hline
\end{tabular}

Note: Final -2loglikelihood $=206.364 ;$ Hosmer and Lemeshow - Chi-square value $=9.102(P=0.334)$;

Nagelkerke $\mathrm{R}^{2}=0.850$; Cox-Snell $\mathrm{R}^{2}=0.638$

$* P<0.05$, ** $P<0.01$ and $* * * P<0.001$

\section{Adapting temporary migration of any member of $\mathrm{HH}$ to another place within 15 years}

The dependent variable; temporary migration has two responses yes and no. No has been taken as reference category for finding the determinants of adaptation practices. Table 6 shows the odds ratio of logistic regression coefficients with their p-values and $95 \%$ confidence interval. Analyses reveal that, as 
household size increases, there is less likely to have adaptation practices. However, as age increases, there is more likely to have adaptation practices. Similarly, other people than Janajati are 14.78 times more likely to adapt temporary migration than upper caste. With reference to illiterate, literate people are more likely to migrate temporarily to another place.

Table 6: Odds Ratio from Logistic Regression Model of Adapting Temporary Migration of any Member to $\mathrm{HH}$ to another Place within 15 years $(n=556)$

\begin{tabular}{|c|c|c|c|}
\hline \multirow[t]{2}{*}{ Characteristics } & \multirow[t]{2}{*}{ Odds Ratio } & \multicolumn{2}{|c|}{$95 \% \mathrm{CI}$} \\
\hline & & Lower & Upper \\
\hline$\overline{\text { Age }}$ & $1.013^{*}$ & 1.000 & 1.062 \\
\hline \multicolumn{4}{|l|}{ Sex } \\
\hline Male (R) & 1 & & \\
\hline Female & 1.047 & 0.535 & 2.049 \\
\hline \multicolumn{4}{|l|}{ Marital status } \\
\hline Married(R) & 1 & & \\
\hline Single & 0.990 & 0.264 & 3.712 \\
\hline \multicolumn{4}{|l|}{ Religion } \\
\hline $\operatorname{Hindu}(\mathrm{R})$ & 1 & & \\
\hline Non-Hindu & 0.943 & 0.431 & 2.063 \\
\hline \multicolumn{4}{|l|}{ Education } \\
\hline Illiterate(R) & 1 & & \\
\hline Literate & $3.838 * * *$ & 1.922 & 7.663 \\
\hline \multicolumn{4}{|l|}{ Caste/Ethnicity } \\
\hline Upper Caste(R) & 1 & & \\
\hline Janajati & 1.34 & 0.583 & 3.082 \\
\hline Others & $14.78^{*}$ & 1.785 & 122.371 \\
\hline Household size & $0.799 * * *$ & 0.716 & 0.891 \\
\hline \multicolumn{4}{|l|}{ Agriculture skill } \\
\hline $\mathrm{Yes}(\mathrm{R})$ & 1 & & \\
\hline No & 1.525 & 0.661 & 3.517 \\
\hline $\begin{array}{l}\text { Years of experience on } \\
\text { agriculture }\end{array}$ & 1.013 & 0.976 & 1.050 \\
\hline
\end{tabular}

Note:Final -2loglikelihood $=275.855$; Hosmer and Lemeshow - Chi-square value $=10.388(p=0.239)$; NagelkerkeR ${ }^{2}=0.786 ;$ Cox-Snell $\mathrm{R}^{2}=0.589$

$* P<0.05$, ** $P<0.01$ and $* * * P<0.001$

\section{Conclusion}

Most of the respondents are male of age 45-59 years, from Janajati, joint family, with basic education, Hindu, married and without agriculture skill. Religion and years of experience on agriculture does not matter for determining the households' adaptation practices towards all selected off-farm activities. Educational status, Janajati with reference to upper caste and agriculture skill are the major determining factors for households' adaptation practices towards change in food consumption habit. Household size is only the matter for determining the households' adaptation practices for shifting to non-agricultural activities. Sex, marital status and agriculture skill matters for determining the households' adaptation practices towards shifted to non-agricultural employment. Age, Educational status, other caste than Janajati with reference to upper caste and household size are the major determining factors for households' adaptation practices towards migration to another places. The findings of this paper may be useful for preparing local adaptation plan of action in the concerned areas. 


\section{Acknowledgement}

This study is fully funded by University Grants Commission (UGC) Nepal under collaborative research grants on Climate Change and Its Impact on Agriculture Sector: Evidence from western Nepal (Award No.: CRG-73/74-Ag \&F-01).

\section{References}

[1] Dhungana A.R. \& Khand P.B. (2019). Determinants of households' adaptation practices against climate change impact on off-farm activities in Nepal. Janapriya Journal of Interdisciplinary studies, 8: 12-25.

[2] Dhungana A.R., KC V.K., Khand P.B. \& Dhungana S.M. (2020). Determinants of households' adaptation practices against climate change impact on off-farm activities in Nawalpur district of western Nepal. SF Journal of Environmental and Earth Science, 3(2): 1-6.

[3] FAO (1998) Rural non-farm income in developing countries: State of food and agriculture. Rome: Food and Agriculture Organization.

[4] Fasona M., Tadross M., Abiodun B., \& Omojola A. (2013). Some implications of terrestrial ecosystems response to climate change for adaptation in Nigeria's wooded savannah. Environmental Development, 5:73-95.

[5] Ghimire Y.N., Shivakoti G.P. \& Perret S. (2010). Household-level vulnerability to drought in hill agriculture of Nepal: Implications for adaptation planning. International Journal of Sustainable Development and World Ecology, 17 (3): 225-230.

[6] Intergovernmental Panel on Climate Change- IPCC (2013) Climate change 2013: The physical science basis; contribution of working group I to the fifth assessment report of the intergovernmental panel on climate change. Cambridge: Cambridge University Press.

[7] Kurukulasuriya P., \& Mendelsohn R.O. (2008). How will climate change shift agro-ecological zones and impact African agriculture? The World Bank development research group sustainable rural and urban development team. Policy Research Working Paper, 1-28.

[8] Lien G., Kumbhakar S.C., \& Hardaker J.B. (2010). Determinants of off-farm work and its effect on farm performance: the case of Norwegian grain farmers. Agriculture Economics, 41: 577-586.

[9] Mabe F.N., Gifty S., \& Samuel D. (2014). Determinants of choice of climate change adaptation strategies in northern Ghana. Research in Applied Economics. 6: 75-94.

[10] MoE (2010). National adaptation programme of action to climate change. Kathmandu: Ministry of Environment, Nepal.

[11] Oppong-Kyeremeh, H. \& Bannor R.K. (2018). Off-farm job as climate change adaptation strategy for small scale rice producers in the Volta region in Ghana. Journal of Energy and Natural Resources Management: Special issue on Environment, Technology and Sustainable Development, 1: 36-42.

[12] Shrestha U.B., Gautam S. \& Bawa K.S. (2012). Widespread climate change in the Himalayas and associated changes in local ecosystems. PloS one, 7, e36741. doi:10.1371/journal.pone.0036741

[13] Wang S.Y., Yoon J.H., Gillies R.R., \& Cho C. (2013). What caused the winter drought in western Nepal during recent years? Journal of Climate, 26: 8241-8256. 